\title{
FAKTOR-FAKTOR MOTIVASI DALAM PEMBELAJARAN BAHASA INGGRIS
}

\author{
Urip Widodo dan Ade Winarti \\ Pendidikan Keagamaan Buddha, STABN Raden Wijaya \\ PGSD Buddha, STABN Raden Wijaya \\ urwido@gmail.com
}

\begin{abstract}
Abstrak: Penelitian ini bertujuan untuk menggali faktor apa saja yang menjadi motivasi siswa dalam belajar bahasa Inggris. Pengumpulan data dilakukan melalui angket untuk mengetahu besaran persentase faktor-faktor dalam pembelajaran bahasa Inggris berdasarkan teori yang sudah ada. Selain itu digunakan wawancara dan observasi untuk mengetahui faktor lain di luar teori yang sudah ada. Analisis data menggunakan analisis deskriptif persentase untuk angket sedangkan untuk wawancara dan observasi data direduksi dan disajikan. Hasil penelitian menunjukkan 13,64\% siswa memiliki motivasi yang sangat baik, 27,27 baik, 40,90 cukup, dan 18,19 kurang. Selain itu faktor-faktor yang mempengaruhi siswa dalam belajar bahasa Inggris adalah guru, tantangan, tes, cita-cita.
\end{abstract}

Kata Kunci: Motivasi, Pembelajaran, Bahasa Inggris.

Abstract: This research aims at describing the motivation factors of learning English. Data collection techniques through questionnaire to know the amount of percentage factors in learning english based on the exsisting theory. Moreover, it is used interview and observation to know the other factors out of the existing theory. Data analysis techniques through descriptive percentage analysis for the quetionnaire, meanwhile interview and observation, the data are reduction and displayed. The results of the research show that $13,64 \%$ students have very good motivation, 27,27\% good, 40,90 fair, and 18,19 lack. Over than that the motivation factors that influence the students to learn English are teacher, challenge, test, and the inspiration or dream.

Key words: motivation, instructional, english.

\section{PENDAHULUAN}

Ahmad (2005:132) menjelaskan ada tiga faktor yang mempengaruhi belajar yaitu faktor internal seperti kesehatan jasmani, tingkat kecerdasan, sikap, bakat, minat, motivasi; dan faktor eksternal seperti sifat-sifat orang tua, praktik pengelolaan keluarga, gedung sekolah dan letaknya, alat-alat belajar; serta faktor pendekatan belajar seperti strategi yang digunakan siswa dalam proses pembelajaran. dalam kegiatan belajarnya. Siswa yang memiliki motivasi belajar maka ia memiliki keinginan berhasil dalambelajar, adanya dorongan dan kebutuhan belajar, memiliki citacita, merasa senang belajar, dan tertarik untuk belajar (Uno, 2008:23). Oleh karena itu, perlu bagi siswa merasa senang belajar, giat belajar dan tekun mengerjakan tugas-tugas, mengulangi pelajaran sepulang sekolah dan berusaha memahami materi pelajaran yang ada 


\section{Jurnal Pendidikan, Sains Sosial dan Agama}

di sekolah, agar tercapai prestasi akademik yang memuaskan.

Belajar merupakan proses kegiatan untuk mengubah tingkah laku subjek belajar.Perubahan tingkah laku tersebut dapat dilihat dari berbagai bentuk, antara lain subjek belajartersebut menjadi kreatif. Kreatifitas dalam belajar ditandai dengan beberapa ciri seperti berpikirterbuka dan bersikap spontan, ingin tahu dan mandiri. Kreatifitas dalam belajar tidak munculbegitu saja akan tetapi dipengaruhi beberapa faktor, baik faktor internal maupun eksternal. Seseorang akan berhasil dan kreatif dalam belajar, jika pada dirinya sendiri ada keinginan untukbelajar. Keinginan atau dorongan untuk belajar inilah yang disebut dengan motivasi.

Berdasarkan asumsi di atas, peserta didik yang memiliki motivasi dalam belajar ditandaidengan suatu perubahan tenaga dalam dirinya, dorongan yang timbul dari dalam diri seseorangberubah menjadi suatu energy yang membuatnya bekerja atau belajar, mencari dan memecahkanmasalah hingga tuntas. Peserta didik yang termotivasi juga membuat reaksireaksi yangmengarahkan dirinya kepada usaha mencapai tujuan.

Menurut banyak pakar, motivasi adalah istilah yang paling sering dipakai untuk menjelaskan keberhasilan atau kegagalan hampir semua tugas yang rumit. Hampir semua pakar juga setuju bahwa suatu teori tentang motivasi berkenaan dengan faktor-faktor yang mendorong tingkah laku dan memberikan arah kepada tingkah laku itu, juga pada umumnya diterima bahwa motif seseorang untuk terlibat dalam satu kegiatan tertentu didasarkan atas kebutuhan yang mendasarinya (Hamid, 1997: 97-98). Motivasi belajar selalu menjadi salah satu faktor keberhasilan belajar seseorang. Seseorang yang memiliki motivasi belajar yang tinggi akan memiliki semangat yang tinggi untuk mengikuti berbagai aktivitas belajar baik yang diminta oleh guru maupun secara mandiri. Motivasi belajar dapat digunakan oleh guru maupun dosen untuk menentukan strategi pembelajaran yang akan dilakukan.

Banyak klasifikasi kebutuhan yang pernah dibuat, tetapi klasifikasi yang paling banyak dirujuk, menurut Brown (2001:74) adalah yang ditampilkan oleh Maslow, yang mengasumsikan hirarki kebutuhan mulai dari kebutuhan fisiologis dasar yang ada sejak lahir (kebutuhan akan makanan, kehangatan, dan lain-lain) hingga ke kebutuhan yang lebih tinggi seperti persetujuan, identitas, harga diri, percapaian, pengetahuan, eksplorasi, yang pemenuhannya mengarah ke aktualisasi diri. Motif yang berdasarkan kebutuhan akan makanan dan sebagainya, disebut motif biologis dan pada pokoknya bersifat bawaan dan motif yang didasarkan atas kebutuhan yang lebih 
tinggi disebut motif psikologis dan pada dasarnya dipengaruhi dengan belajar dan faktor

lingkungan. Motif yang terakhir ini terutama relevan dengan penelitian belajar bahasa kedua.

Motivasi memainkan peranan penting dalam menumbuhkan minat pembelajar. Begitu halnya dalam pembelajaran bahasa, motivasi berkontribusi besar dalam meningkatkan kemampuan pembelajar dengan beragam caranya. Penelitian tentang motivasi pembelajaran bahasa asing terfokus pada faktor-faktor yang menjadikan seseorang ingin mempelajari bahasa asing dan apa yang menjaganya agar senantiasa termotivasi untuk mempelajari bahasa asing tersebut. Peranan motivasi dalam pembelajaran bahasa asing merupakan hal yang kompleks, mengingat bahasa senantiasa terikat konteks sosial dan budaya. Lebih spesifik lagi, penguasaan bahasa asing juga merupakan peristiwa sosial yang selalu diiringi oleh unsur-unsur kebudayaan dari bahasa asing itu sendiri.

Dalam konteks pemerolehan dan pembelajaran bahasa kedua (asing), salah satu faktor yang diyakini membangun motivasi itu adalah sikap terhadap bahasa dan budaya dari masyarakat yang menggunakan bahasa tersebut. (Gardner dalam Kholid, 2017: 62). Gagne (1998: 234) mengemukakan tiga aspek dari sikap sebagai berikut : 1) komponen kognitif, yang merujuk kepada keyakinan seseorang tentang suatu objek; 2) komponen afektif, yang merujuk ke jumlah perasaan positif atau negatif yang dipunyai seseorang terhadap objek tertentu; 3) komponen behavioral, yang merujuk kepada niat tingkah laku seseorang atau merujuk kepada tingkah laku aktual terhadap objek itu.

Menurut data yang dilansir English First - English Proficiency Index (EF EPI), menunjukan Indonesia menempati urutan ke-28 dari 63 negara di dunia dalam hal indekskemampuan berbahasa Inggris. Survei tersebut melibatkan 750.000 responden. Sebanyak $52.74 \%$ penduduk Indonesia memiliki kemampuan bahasa Inggris dengan kategori rata-rata.Sementara, negara tetangga seperti Singapura berada di urutan 13 (59.8\%) dan Malaysia diurutan 12 (59.73\%) dengan kemampuan berbahasa Inggris pada kategori tinggi.

Berbagai kajian dan penelitian tentang pengajaran dan pembelajaran bahasa Inggris diIndonesia telah banyak dilakukan. Beberapa faktor dianggap memiliki peran yang sangatsignifikan dalam keberhasilan pengajaran bahasa Inggris. Faktor-faktor tersebut diantaranyaadalah pengajar, siswa, kurikulum, materi ajar, dan fasilitas pembelajaran. Berbicara tentangsiswa sebagai salah satu unsur pembelajaran yang penting, tidak dapat dilepaskandari pembahasan mengenai motivasi. 
Motivasi siswa hingga saat ini diyakini sebagaiunsur pembelajaran yang menentukan keberhasilan belajar siswa. Beberapa hasil penelitiantentang motivasi dalam pembelajaran bahasa asing menunjukkan bahwa motivasi pemelajardalam mempelajari bahasa asing merupakan penggerak utama yang membawanya padakeberhasilan mempelajari bahasa asing tersebut.

Motivasi dalam mempelajari bahasa asing bervariasi. Seorang individu dapatmempelajari bahasa asing karena ia memiliki kepentingan dengan bahasa tersebut, misalnya iahendak bekerja di negara berbahasa asing tersebut sehingga memiliki keahlian berbahasanegara tersebut mutlak diperlukan. Selain itu, bisa saja seseorang mempelajari bahasa asingkarena ingin mempelajari kebudayaan bangsa lain. Motivasi lain yang sangat mungkinmuncul adalah keinginan seseorang untuk menguasai bahasa asing, terutama bahasa-bahasa internasional seperti bahasa Inggris, bahasa Perancis, bahasa Mandarin, dan sebagainya untukmembuatnya mudah mencari pekerjaan.

\section{METODOLOGI}

Pendekatan penelitian ini bersifat deskriptif dapat diartikan sebagai prosedur pemecahan masalah yang diselidiki, dengan menggambarkan atau melukiskan keadaan objek penelitian pada saat sekarang, berdasarkan fakta-fakta yang tampak atau sebagaimana adanya.Penelitian ini merupakan penelitian studi kasus dikarenakan terdapat sejumlah kejadian yang menunjukkan adanya motivasi dan demotivasi pada pembelajaran bahasa Inggris yang terjadi pada siswa beragama Buddha yang dibuktikan dengan nilai akhir siswa yang masih dibawah standar yang telah ditetapkan.

Pada dasarnya penelitian dengan jenis studi kasus bertujuan untuk mengetahui tentang sesuatu hal secara mendalam. Maka dalam penelitian ini, peneliti akan menggunakan metode studi kasus untuk mengungkap tentang faktor-faktor baik motivasi maupun demotivasi belajar dalam pembelajaran bahasa Inggris. Melalui pendekatan studi kasus diharapkan diketahui apa saja faktor-faktor yang menyebabkan motivasi dan demotivasi pada pembelejaran bahasa Inggris sehingga harapannya dapat memberikan dampak yang positif bagi siswa. Alasan pemilihan pendekatan ini adalah ingin mengetahui makna berkaitan dengan faktorfaktor baik motivasi maupun demotivasi belajar pada pembelajaran bahasa Inggris.

Penelitian ini akan dilaksanakan di Kabupaten Banjarnegara. Pemilihan tempat di Kabupaten Banjarnegara didasarkan pada: 1) Nilai bahasa Inggris siswa beragama Buddha 
yang rendah bahkan jika dibandingkan dengan berbagai tempat di Kabupaten lain; 2) Tingkat kedisiplinan siswa yang masih kurang; 3) Jarak antara rumah dengan sekolah yang cukup jauh. Secara keseluruhan penelitian ini akan dilaksanakan pada bulan Agustus-Desember tahun 2019.

Variabel-variabel yang ada
pengukuran. Variabel opersional dari motivasi belajar adalah dorongan yang ada dalam diri seseorang untuk belajar yang disertai dengan perasaan senang dan gembira dalam melakukan aktivitas belajar tersebut. melalui motivasi belajar siswa diharapkan memiliki semangat yang tinggi dalam kegiatan belajarnya sehingga menghasilkan prestasi belajar yang baik. Faktor motivasi belajar meliputi: 1) Cita-cita atau aspirasi siswa; 2) Kemampuan belajar; 3) Kondisi jasmani dan rohani siswa; 4) Kondisi lingkungan kelas; 5) Unsur-unsur dinamis belajar; 6) Upaya guru membelajarkan siswa.

Menurut Arikunto (2013 : 200)

subjek penelitian adalah benda, hal atau organisasi tempat data atau variabel penelitian yang dipermasalahkan melekat. Tidak ada satu pun penelitian yang dapat dilakukan tanpa adanya subjek penelitian, karena seperti yang telah diketahui bahwa dilaksanakannya penelitian dikarenakan adanya masalah yang harus dipecahkan, maksud dan tujuan penelitian adalah untuk memecahkan persoalan yang timbul tersebut. Hal ini dilakukan dengan jalan mengumpulkan data sebanyak-banyaknya dari informan.

Subjek penelitian ini adalah seluruh siswa beragama Buddha tingkat SMA di Kabupaten Banjarnegara. Berdasarkan data yang diperoleh jumlah seluruh siswa bergama Buddha tingkat SMA yaitu 22 siswa. Keseluruhan siswa akan dijadikan responden penelitian dikarenakan jumlahnya yang tidak begitu banyak. Siswa-siswa tersebut berasal dari 3 kecamatan yaitu Kecamatan Pagentan, Kecamatan Purwanegara, dan Kecamatan Susukan. Selain itu siswa-siswa tersebut juga tersebar dalam 4 Sekolah Menengah, yaitu SMAN 1 Sigaluh, SMKN 1 Bawang, SMAN 1 Banjarnegara, dan SMAN 1 Purwareja Klampok. Adapun rincian jumlah siswa pada setiap kecamatan adalah sebagai berikut:

Tabel 3.2.

Sebaran Jumlah Siswa

\begin{tabular}{|l|l|l|}
\hline No & \multicolumn{1}{|c|}{ Kecamatan } & \multicolumn{1}{|c|}{$\begin{array}{c}\text { Jumlah } \\
\text { Siswa }\end{array}$} \\
\hline 1. & Pagentan & 15 \\
\hline 2. & Purwanegara & 6 \\
\hline 3. & Susukan & 1 \\
\hline
\end{tabular}

Teknik pengumpulan data merupakan alat-alat pengukur yang diperlukan dalam melaksanakan suatu penelitian. Data 
yang akan dikumpulkan dapat berupa angkaangka, keterangan tertulis, informasi lisan dan beragam fakta yang berhubungan dengan fokus penelitian yang diteliti. Teknik pengumpulan data dalam penelitian ini menggunakan angket, angket merupakan suatu daftar isi pertanyaanpertanyaan yang harus dijawab atau dikerjakan oleh orang yang diselidiki atau yang disebut dengan responden (Arikunto, 2013: 66).

Metode angket sesuai untuk mengukur kemampuan atau suatu hal yang bersifat abstrak sehingga menjadi lebih konkret melalui konversi angka-angka. Angka-angka kemudian dianalisis sehingga mampu menjabarkan dimensi dari sebuah variabel masalah penelitian. Angket yang dligunakan dalam penelitian ini merupakan jenis angket terbuka yaitu angket dimana responden disediakan pilihan-pilihan jawaban yang ada. Pilihan jawaban pernyataan mulai dari sangat setuju sampai dengan sangat tidak setuju. Penyusunan angket dilaksanakan dengan terlebih dahulu menemukan indikator pada masing-masing variabel, mulai dari variabel kreativitas belajar dan kemampuan membaca. Kemudian, dilanjutkan dengan membuat kisi-kisi angket. Adapun kisi-kisi angket dalam penelitian ini adalah sebagai berikut:

Tabel 1

Kisi-Kisi Angket

\begin{tabular}{|l|l|l|l|}
\hline No & $\begin{array}{l}\text { Variabe } \\
1\end{array}$ & Indikator & No Pernyataan \\
\hline
\end{tabular}

\begin{tabular}{|c|c|c|c|}
\hline \multirow{6}{*}{1} & \multirow{6}{*}{$\begin{array}{l}\text { Motiva } \\
\text { si } \\
\text { Belajar }\end{array}$} & $\begin{array}{l}\text { Cita-cita } \\
\text { atau aspirasi } \\
\text { siswa }\end{array}$ & $1,2,3^{*}, 4,5$ \\
\hline & & $\begin{array}{l}\text { Kemampuan } \\
\text { belajar }\end{array}$ & $5,6,7,8,9^{*}, 10$ \\
\hline & & $\begin{array}{l}\text { Kondisi } \\
\text { jasmani dan } \\
\text { rohani siswa }\end{array}$ & $\begin{array}{l}11,12,13,14,15 \\
*\end{array}$ \\
\hline & & $\begin{array}{l}\text { Kondisi } \\
\text { lingkungan } \\
\text { kelas }\end{array}$ & $\begin{array}{l}16,17^{*}, 18,19,2 \\
0\end{array}$ \\
\hline & & $\begin{array}{l}\text { Unsur-unsur } \\
\text { dinamis } \\
\text { belajar }\end{array}$ & $\begin{array}{l}21,22,23,24 *, 2 \\
5\end{array}$ \\
\hline & & $\begin{array}{l}\text { Upaya guru } \\
\text { membelajark } \\
\text { an siswa }\end{array}$ & $\begin{array}{l}26^{*}, 27,28,29,3 \\
0\end{array}$ \\
\hline
\end{tabular}

Selain angket digunakan teknik observasi, wawancara, dan dokumentasi untuk menjawab masalah berkaitan dengan faktorfaktor yang ada di luar teori yang sudah dipaparkan. Analisis data angket menggunakan teknik deskriptif persentase sedangkan data dari observasi, wawancara, dan dokumentasi menggunakan reduksi data, penyajian data, dan penarikan kesimpulan.

\section{HASIL DAN PEMBAHASAN}

\section{Analisis Deskriptif Persentase}

Analisis deskriptif persentase terhadap skor yang diperoleh digunakan untuk mengetahui gambaran jawaban responden terkait motivasi dan demotivasi pada pembelajaran bahasa Inggris.

\section{a. Variabel Motivasi Pembelajaran Bahasa Inggris}


Berikut ini adalah hasil analisis deskriptif persentase pada variabel motivasi pembelajaran bahasa Inggris:

\section{Tabel 2}

Hasil Perhitungan Deskriptif Persentase

Variabel Motivasi Pembelajaran Bahasa

Inggris

\begin{tabular}{|c|c|c|c|c|}
\hline $\begin{array}{c}\text { N } \\
\text { o }\end{array}$ & $\begin{array}{c}\text { Interva } \\
\mathbf{l}\end{array}$ & $\begin{array}{c}\text { Frekuen } \\
\text { si }\end{array}$ & $\begin{array}{c}\text { Persentas } \\
\mathbf{e}\end{array}$ & $\begin{array}{c}\text { Kriteri } \\
\mathbf{a}\end{array}$ \\
\hline 1. & $\begin{array}{c}81,25 \% \\
- \\
100,00 \\
\%\end{array}$ & 3 & $13,64 \%$ & $\begin{array}{c}\text { Sangat } \\
\text { Baik }\end{array}$ \\
\hline 2. & $\begin{array}{c}62,50 \% \\
- \\
81,25 \%\end{array}$ & 6 & $27,27 \%$ & Baik \\
\hline 3. & $\begin{array}{c}43,75 \% \\
-\end{array}$ & 9 & $40,90 \%$ & Cukup \\
\hline 4. & $\begin{array}{c}25,00 \% \\
-\end{array}$ & 4 & $18,19 \%$ & Kurang \\
\hline $43,73 \%$
\end{tabular}

Berdasarkan tabel di atas terlihat bahwa sebagian besar motivasi belajar bahasa Inggris termasuk dalam kategori cukup, yaitu sebesar 40,90\%. Selain itu terdapat 3 siswa dengan persentase $13,64 \%$ yang masuk dalam kategori sangat baik dan 6 siswa dengan persentase $27,27 \%$ yang masuk dalam kategori baik, namun terdapat 4 siswa yang masuk dalam kategori motivasi belajar bahasa Inggris yang kurang dengan persentase sebesar $18,18 \%$. Pada penelitian ini motivasi belajar diukur dengan indikator cita-cita atau aspirasi siwa, kemampuan belajar, kondisi jasmani dan rohani siswa, kondisi lingkungan kelas, unsurunsur dinamis belajar dan upaya guru membelajarkan siswa.

\section{1) Cita-cita atau aspirasi siswa}

Hasil analisis deskriptif berdasarkan indikator cita-cita atau aspirasi siswa adalah sebagai berikut:

\section{Tabel 3}

Hasil Perhitungan Deskriptif Persentase

Indikator Cita-cita atau aspirasi siswa

\begin{tabular}{|c|c|c|c|c|}
\hline $\begin{array}{l}\mathbf{N} \\
\mathbf{0}\end{array}$ & $\begin{array}{c}\text { Interva } \\
\text { l }\end{array}$ & $\begin{array}{c}\text { Frekuen } \\
\text { si }\end{array}$ & $\begin{array}{c}\text { Persentas } \\
\text { e }\end{array}$ & $\begin{array}{c}\text { Kriteri } \\
\mathbf{a}\end{array}$ \\
\hline 1. & $\begin{array}{c}81,25 \% \\
- \\
100,00 \\
\%\end{array}$ & 6 & $27,27 \%$ & $\begin{array}{c}\text { Sangat } \\
\text { Baik }\end{array}$ \\
\hline 2. & $\begin{array}{c}62,51 \% \\
- \\
81,24 \%\end{array}$ & 6 & $27,27 \%$ & Baik \\
\hline 3. & $\begin{array}{c}43,76 \% \\
- \\
62,50 \% \\
\end{array}$ & 6 & $27,27 \%$ & Cukup \\
\hline 4. & $\begin{array}{c}25,00 \% \\
- \\
43,75 \%\end{array}$ & 4 & $18,19 \%$ & Kurang \\
\hline \multicolumn{2}{|c|}{ Jumlah } & 22 & $100 \%$ & \\
\hline
\end{tabular}

Berdasarkan tabel tersebut terlihat bahwa variabel motivasi belajar bahasa Inggris dengan indikator cita-cita atau aspirasi siwa menunjukkan sebanyak 6 siswa dengan persentase $27,27 \%$ pada kriteria sangat baik. Sebanyak 6 siswa dengan persentase 27,27\% pada kriteria baik. Adapun siswa yang masuk dalam kategori cukup adalah sebanyak 6 siswa 
dengan persentase $27,27 \%$, sedangkan pada kriteria kurang dengan persentase 18,19 terdapat 4 siswa.

\section{2) Kemampuan Belajar}

Hasil analisis deskriptif berdasarkan indikator kemampuan belajar adalah sebagai berikut:

Tabel 4

Hasil Perhitungan Deskriptif Persentase Indikator Kemampuan Belajar

\begin{tabular}{|c|c|c|c|c|}
\hline $\begin{array}{l}\mathbf{N} \\
\mathbf{0}\end{array}$ & $\begin{array}{c}\text { Interva } \\
\text { l }\end{array}$ & $\begin{array}{c}\text { Frekuen } \\
\text { si }\end{array}$ & $\begin{array}{c}\text { Persentas } \\
\text { e }\end{array}$ & $\begin{array}{c}\text { Kriteri } \\
\mathbf{a}\end{array}$ \\
\hline 1. & $\begin{array}{c}81,26 \% \\
- \\
100,00 \\
\%\end{array}$ & 5 & $22,73 \%$ & Tinggi \\
\hline 2. & $\begin{array}{c}62,51 \% \\
- \\
81,25 \%\end{array}$ & 8 & $36,36 \%$ & Baik \\
\hline 3. & $\begin{array}{c}43,76 \% \\
- \\
62,50 \%\end{array}$ & 9 & $40,91 \%$ & Cukup \\
\hline 4. & $\begin{array}{c}25,00 \% \\
- \\
43,75 \%\end{array}$ & 0 & $0 \%$ & Kurang \\
\hline \multicolumn{2}{|c|}{ Jumlah } & 22 & $100 \%$ & \\
\hline
\end{tabular}

Berdasarkan tabel tersebut terlihat bahwa variabel motivasi belajar dengan indikator kemampuan belajar menunjukkan sebanyak 5 siswa dengan persentase $22,73 \%$ pada kriteria sangat baik. Sebanyak 8 siswa dengan persentase $36,36 \%$ pada kriteria baik. Adapun siswa yang mempunyai kemampuan belajar yang cukup yaitu sebanyak 9 siswa dengan persentase $40,91 \%$. Selain itu pada indikator kemampuan belajar tidak ada siswa yang memiliki kemampuan belajar kurang.

\section{3) Kondisi Jasmani dan Rohani}

Hasil analisis deskriptif persentase pada variabel motivasi belajar belajar dengan indikator kondisi jasmani dan rohani adalah sebagai berikut:

\section{Tabel 5}

Hasil Perhitungan Deskriptif Persentase Indikator Kondisi Jasmani dan Rohani

\begin{tabular}{|c|c|c|c|c|}
\hline $\begin{array}{l}\mathbf{N} \\
\mathbf{0}\end{array}$ & $\begin{array}{c}\text { Interva } \\
\text { l }\end{array}$ & $\begin{array}{c}\text { Frekuen } \\
\text { si }\end{array}$ & $\begin{array}{c}\text { Persentas } \\
\text { e }\end{array}$ & $\begin{array}{c}\text { Kriteri } \\
\quad \mathbf{a}\end{array}$ \\
\hline 1. & $\begin{array}{c}81,26 \% \\
- \\
100,00 \\
\%\end{array}$ & 2 & $9,10 \%$ & $\begin{array}{c}\text { Sangat } \\
\text { Baik }\end{array}$ \\
\hline 2. & $\begin{array}{c}62,51 \% \\
- \\
81,25 \%\end{array}$ & 9 & $40,90 \%$ & Baik \\
\hline 3. & $\begin{array}{c}43,76 \% \\
- \\
62,50 \%\end{array}$ & 10 & $45,45 \%$ & Cukup \\
\hline 4. & $\begin{array}{c}25,00 \% \\
- \\
43,75 \%\end{array}$ & 1 & $4,55 \%$ & Kurang \\
\hline \multicolumn{2}{|c|}{ Jumlah } & 22 & $100 \%$ & \\
\hline
\end{tabular}

Berdasarkan tabel tersebut terlihat bahwa variabel motivasi belajar dengan indikator kesehatan jasmani dan rohani menunjukkan sebanyak 2 siswa dengan persentase $9,10 \%$ pada kriteria sangat baik. Sebanyak 9 siswa dengan persentase $40,90 \%$ pada kriteria baik. Adapun siswa yang memiliki kondisi jasmani 
dan rohani cukup yaitu sebanyak 10 siswa dengan persentase $45,45 \%$. Selain itu pada indikator kondisi jasmani dan rohani hanya ada 1 siswa dengan persentase 4,55\% yang memiliki yang masuk dalam kategori kurang.

\section{4) Kondisi Lingkungan Kelas}

Hasil analisis deskriptif persentase pada variabel motivasi belajar dengan indikator kondisi lingkungan kelas adalah sebagai berikut:

\section{Tabel 6}

Hasil Perhitungan Deskriptif Persentase Indikator Kondisi Lingkungan Kelas

\begin{tabular}{|c|c|c|c|c|}
\hline $\begin{array}{l}\mathbf{N} \\
\mathbf{0}\end{array}$ & $\begin{array}{c}\text { Interv } \\
\text { al }\end{array}$ & $\begin{array}{c}\text { Frekue } \\
\text { nsi }\end{array}$ & $\begin{array}{l}\text { Persent } \\
\text { ase }\end{array}$ & $\begin{array}{c}\text { Krite } \\
\text { ria }\end{array}$ \\
\hline 1. & $\begin{array}{c}81,26 \\
\%- \\
100,00 \\
\%\end{array}$ & 5 & $22,73 \%$ & $\begin{array}{l}\text { Sanga } \\
\text { t Baik }\end{array}$ \\
\hline 2. & $\begin{array}{c}62,51 \\
\%- \\
81,25 \\
\%\end{array}$ & 2 & $9,10 \%$ & Baik \\
\hline 3. & $\begin{array}{c}43,76 \\
\%- \\
62,50 \\
\%\end{array}$ & 10 & $45,44 \%$ & Cukup \\
\hline 4. & $\begin{array}{c}25,00 \\
\%- \\
43,75 \\
\%\end{array}$ & 5 & $22,72 \%$ & $\begin{array}{c}\text { Kuran } \\
\mathrm{g}\end{array}$ \\
\hline \multicolumn{2}{|c|}{ Jumlah } & 22 & $100 \%$ & \\
\hline
\end{tabular}

Berdasarkan tabel tersebut terlihat bahwa variabel motivasi belajar belajar dengan indikator kondisi lingkungan kelas menunjukkan sebanyak 5 siswa dengan persentase $22,73 \%$ pada kriteria sangat baik. Sebanyak 2 siswa dengan persentase 9,10\% pada kriteria baik. Adapun siswa yang mempunyai inisiatif yang cukup yaitu sebanyak 10 siswa dengan persentase $45,44 \%$. Terlebih lagi ada 5 siswa dengan persentase $22,73 \%$ yang memiliki keinginan untuk berprestasi kurang.

\section{5) Unsur-unsur Dinamis Belajar}

Hasil analisis deskriptif persentase pada variabel motivasi belajar dengan indikator unsur-unsur dinamis belajar adalah sebagai berikut:

\section{Tabel 7}

Hasil Perhitungan Deskriptif Persentase

Indikator Unsur-Unsur Dinamis Belajar

\begin{tabular}{|c|c|c|c|c|}
\hline $\begin{array}{c}\mathbf{N} \\
\mathbf{0}\end{array}$ & $\begin{array}{c}\text { Interva } \\
\mathbf{l}\end{array}$ & $\begin{array}{c}\text { Frekuen } \\
\mathbf{s i}\end{array}$ & $\begin{array}{c}\text { Persentas } \\
\mathbf{e}\end{array}$ & $\begin{array}{c}\text { Kriteri } \\
\mathbf{a}\end{array}$ \\
\hline 1. & $\begin{array}{c}81,26 \% \\
- \\
100,00 \\
\%\end{array}$ & 7 & $31,81 \%$ & $\begin{array}{c}\text { Sangat } \\
\text { Baik }\end{array}$ \\
\hline 2. & $\begin{array}{c}62,51 \% \\
- \\
81,25 \%\end{array}$ & 11 & $50 \%$ & Baik \\
\hline 3. & $\begin{array}{c}43,76 \% \\
-\end{array}$ & 3 & $13,64 \%$ & Cukup \\
\hline $42,50 \%$ & $\begin{array}{c}25,00 \% \\
-\end{array}$ & 1 & $4,55 \%$ & Kurang \\
\hline \multicolumn{2}{|c|}{ Jumlah } & 22 & $100 \%$ & \\
\hline
\end{tabular}




\section{Jurnal Pendidikan, Sains Sosial dan Agama}

Berdasarkan tabel tersebut terlihat bahwa variabel motivasi belajar dengan indikator unsur-unsur dinamis belajar menunjukkan sebanyak 7 siswa dengan persentase $31,81 \%$ pada kriteria sangat baik. Sebanyak 11 siswa dengan persentase $50,00 \%$ pada kriteria baik. Adapun siswa sebanyak 3 siswa dengan persentase $13,64 \%$ dengan kriteria cukup. Terlebih lagi ada 1 siswa dengan persentase $4,55 \%$ yang masuk dalam kategori kurang.

\section{6) Upaya Membelajarkan Siswa}

Hasil analisis deskriptif persentase pada variabel motivasi belajar dengan indikator upaya membelajarkan siswa adalah sebagai berikut:

\section{Tabel 8}

Hasil Perhitungan Deskriptif Persentase

Indikator Upaya Membelajarkan Siswa

\begin{tabular}{|c|c|c|c|c|}
\hline $\begin{array}{c}\mathrm{N} \\
\mathrm{o}\end{array}$ & Interval & $\begin{array}{c}\text { Frekuens } \\
\mathrm{i}\end{array}$ & $\begin{array}{c}\text { Persentas } \\
\mathrm{e}\end{array}$ & $\begin{array}{c}\text { Kriteri } \\
\mathrm{a}\end{array}$ \\
\hline 1. & $\begin{array}{c}81,26 \% \\
- \\
100,00 \\
\%\end{array}$ & 3 & $13,63 \%$ & $\begin{array}{c}\text { Sangat } \\
\text { Baik }\end{array}$ \\
\hline 2. & $\begin{array}{c}62,51 \% \\
- \\
81,25 \%\end{array}$ & 13 & $59,10 \%$ & Baik \\
\hline 3. & $\begin{array}{c}43,76 \% \\
- \\
62,50 \%\end{array}$ & 5 & $22,73 \%$ & Cukup \\
\hline 4. & $\begin{array}{c}25,00 \% \\
-\end{array}$ & 1 & $4,54 \%$ & Kurang \\
\hline \multicolumn{2}{|c|}{ Jumlah } & 22 & $100 \%$ & \\
\hline
\end{tabular}

Berdasarkan tabel tersebut terlihat bahwa variabel motivasi belajar dengan indikator upaya membelajarkan siswa menunjukkan sebanyak 3 siswa dengan persentase $13,63 \%$ pada kriteria sangat baik. Sebanyak 13 siswa dengan persentase $59,10 \%$ pada kriteria baik. Adapun yang masuk dalam kategori cukup yaitu sebanyak 5 siswa dengan persentase $22,73 \%$. Terlebih lagi ada 1 siswa dengan persentase $4,55 \%$ yang masuk dalam kategori kurang.

\section{Faktor-Faktor yang Menjadi Motivasi} Belajar Siswa dalam Pembelajaran Bahasa Inggris

Untuk mengetahui faktor-faktor apa saja yang menjadi motivasi siswa dalam pembelajaran bahasa Inggris digunakan teknik pengumpulan data berupa wawancara, observasi, dan dokumentasi. Wawancara mendalam dilakukan beberapa kali sampai data yang dikumpulkan berada pada titik keajegannya. Berdasarkan teknik-teknik yang digunakan tersebut maka secara garis besar terdapat 4 hal yang menjadi motivasi siswa dalam pembelajaran bahasa Inggris. Berikut ini keempat hal tersebut beserta pengelompokan jumlah responden yang memilihnya.

Tabel 9 
Faktor-Faktor yang Menjadi Motivasi

Belajar Bahasa Inggris

\begin{tabular}{|c|c|}
\hline Faktor-faktor & $\begin{array}{c}\text { Jumlah Responden } \\
\text { yang memilih }\end{array}$ \\
\hline Guru & 20 \\
\hline Tantangan & 12 \\
\hline Ujian & 8 \\
\hline Cita-cita atau Aspirasi & 6 \\
\hline
\end{tabular}

a) Guru

Guru menjadi salah satu faktor yang mampu memotivasi siswa dalam pembelajaran bahasa Inggris. Guru merupakan sosok sentral dalam kegiatan pembelajaran. Bagaimanapun juga keberlangsungan pembelajaran bergantung pada guru. Sejumlah siswa beragama Buddha mengungkapkan bahwa semangat tidaknya untuk mengikuti dan belajar bahasa Inggris sangat bergantung pada gurunya. Seorang siswa mengungkapkan:

"saya sangat antusias mengikuti pembelajaran bahasa Inggris karena gurunya tidak sombong selain itu gurunya juga ramah cara mengajarnya sangat enak, ketika saya menemui kesulitan dalam mengerjakan soal guru juga mampu membantu menyelesaikan permasalahan dengan mudah dipahami”

Siswa yang lain mengatakan: "pembelajaran di kelas bahasa Inggris sangat menarik karena gurunya lucu, tapi juga menerangkannya mudah dipahami. Guru bahasa Inggris itu salah satu guru favorit saya jadi saya sangat semangat belajar bahasa Inggris"

Berdasarkan pernyataan-pernyataan di atas diketahui bahwa peran guru dalam kaitannya dengan motivasi belajar siswa sangat penting. Guru yang mampu memposisikan diri dengan baik dan mampu mengambil hati para siswanya akan menjadi faktor motivasi yang sangat kuat bagi siswa untuk belajar. Pernyataan di bawah ini memperkuat faktor guru sebagai salah satu faktor yang dapat menentukan motivasi belajar siswa:

"kalau ditanya apa yang paling membuat saya semangat belajar bahasa Inggris alasannya adalah karena guru bahasa Inggris saya merupakan salah satu guru terbaik. Kenapa terbaik karena guru bahasa Inggris saya rela berulang kali mengulang materi utamanya biasanya grammar sampai memastikan seтиa siswa bisa mengerjakan soal. Saya sangat salut dengan hal itu"

Jika melihat pernyataan di atas maka pada prinsipnya guru yang mampu memotivasi siswa adalah guru yang memiliki teknik dan strategi tersendiri dalam mengelola kelasnya sehingga seluruh siswa merasa menjadi bagian dari kelas yang harus bmemberikan kontribusi 


\section{Jurnal Pendidikan, Sains Sosial dan Agama}

dan mampu menyelesaikan masalah, selain itu guru juga mampu menunjukkan bahwa semua siswa adalah sama dan akan mendapatkan perhatian yang sama.

\section{b) Tantangan}

Pembelajaran bahasa Inggris memiliki karakteristik tersendiri. Dalam pembelajaran bahasa Inggris terdapat berbagai cara yang dapat dilakukan untuk memberikan tantangan kepada para pembelajarnya agar memiliki semangat yang tinggi untuk belajar dan meningkatkan kemampuan bahasa Inggris yang dimiliki. Tantangan merupakan hal yang sangat tepat diberikan kepada para siswa yang sejak awal sudah memiliki minat dan ketertarikan yang tinggi terhadap sesuatu. Melalui tantangan maka para siswa akan berusaha memberikan seluruh potensi yang dimiliki untuk menyelesaikan maupun menjawab tantangan yang diberikan.

Berkaitan dengan tantangan ini sejumlah siswa memberikan pernyataannya:

"ketika pembelajaran bahasa Inggris kadang para siswa diminta untuk mewawancarai teman dari kelas yang berbeda dengan menggunakan bahasa Inggris. saya sangat antusias jika kegiatan-kegiatan yang unik kaya ini dilakukan, karena tidak biasa jadi rasa deg-degannya besar banget. Takut sih tapi menyenangkan"

Berdasarkan pernyataan tersebut dapat dilihat bahwa sebetulnya kegiatankegiatan atau aktivitas-aktivitas pembelajaran yang dilakukan diluar kebiasaan yang ada justru mampu membuat siswa merasa senang dan antusias. Siswa merasa tergerak hati dan pikirannya untuk dapat menyelesaikan tugas yang diberikan, terlebih lagi tugas tersebut berhubungan dengan teman di luar kelasnya sehingga para siswa harus mampu menunjukkan kemampuan terbaiknya. Kegiatan tersebut di atas dapat digolongkan ke-dalam kegiatan yang menantang karena siswa diharuskan untuk mampu menunjukkan kemampuan terbaiknya di depan siswa lain dari kelas yang berbeda.

Berkaitan dengan tantangan ini salah satu guru bahasa Inggris juga membenarkan hal tersebut. Guru tersebut mengungkapkan bahwa pada saat kegiatan pembelajaran tidak hanya dilaksanakan di ruang kelas namun juga di luar ruangan. Kegiatan di luar ruangan pada umumnya merupakan aktivitas speaking (berbicara) di mana aktivitas ini menuntut siswa untuk berani dan percaya diri ketika berbicara baik dengan sesama teman sekelas maupun dengan teman dari kelas lain, bahkan pernah juga diminta untuk mewawancarai salah satu guru dengan menggunakan bahasa Inggris. 


\section{Jurnal Pendidikan, Sains Sosial dan Agama}

c) Tes

Tes adalah kegiatan biasa yang umum digunakan dan dilaksanakan pada berbagai mata pelajaran bahkan tes ini merupakan sebuah kegiatan yang wajib dilaksanakan oleh guru. Melalui tes siswa akan terdorong untuk belajar sehingga mendapatkan nilai yang terbaik. Tidak dapat dipungkiri bahwa tes sering kali menjadi salah satu cara untuk mendorong siswa agar belajar. Hal tersebut juga terjadi pada siswa beragama Buddha tingkat SMA di Kabupaten Banjarnegara yang mana para siswa akan sangat bersemangat untuk belajar jika akan ada tes.

Berikut ini pernyataan-pernyataan yang diberikan oleh siswa berkaitan dengan tes sebagai salah satu faktor yang mampu memotivasi siswa untuk belajar.

"kalau ditanya hal apa yang membuat saya belajar bahasa inggris jwabannya karena mau ada ulangan atau ujian atau tes. Jika mau ada tes maka saya akan meluangkan waktu tersendiri untuk belajar. Dalam satu minggu biasanya paling tidak dua kali belajar sebelum ada tes” "saya akan belajar bahasa Inggris dengan serius kalau mau ada ujian atau ulangan. Saya takut nilai saya akan jelek kalau saya tidak belajar, dan saya juga tidak mau remidi" "jujur kalau tidak ada ujian atau ulangan saya jarang belajar bahasa Inggris tapi kalau mau ulangan saya pasti belajar, bahkan kadang sampai diulang-ulang sampai saya paham, terutama yang tenses-tenses karena itu yang menurut saya paling sulit"

Dari pendapat-pendapat siswa di atas terlihat bahwa para siswa akan semnagat untuk belajar jika akan ada ujian atau ulangan harian. Berdasarkan hasil pengamatan memang terlihat sejumlah siswa meluangkan waktunya untuk belajar ketika akan ada ulangan. Dan sebaliknya kalau tidak ada ujian atau tes memang sejumlah siswa jarang untuk belajar bahasa Inggris.

\section{d) Cita-cita atau Keinginan}

Cita-cita atau keinginan adalah harapan yang menjadi impian banyak siswa sehingga timbul dorongan yang tinggi untuk mencapainya. Melalui dorongan yang tinggi tersebut para siswa akan berusaha menunjukkan kemampuan terbaiknya sehingga apa yang diharapkan dan dictia-citakan dapat terwujud. Terdapat berbagai angan-angan, harapan, dan cita-cita dari para siswa berkaitan dengan bahasa Inggris yang diungkapkan. Berikut ini adalah apa yang disampaikan oleh siswa: 
Jurnal Pendidikan, Sains Sosial dan Agama

"saya senang dan semangat belajar bahasa Inggris karena saya ingin seperti guru saya, pak Tuswadi yaitu seorang guru bahasa Ingggris yang sangat terkenal di Kabupaten Banjarnegara. Satu-satunya guru bahasa Inggris yang sudah S-3 di Jepang. Saya sangat ingin seperti beliau"

"saya senang bahasa Inggris karena saya ingin lancar ngomong bahasa Inggris, karena bahasa Inggris bahasa internasional jika saya bisa lancar ngomong bahasa Inggris maka saya akan mudah mencari pekerjaan dan saya juga bisa melanjutkan ke perguruan tinggi dengan mudah"

"saya giat belajar bahasa Inggris karena saya ingin bekerja di luar negeri seperti kakak saya, katanya kalau saya bisa berbahasa Inggris dengan baik maka saya akan mudah diterima bekerja di luar negeri karena gajinya juga besar"

Dari pernyataan-pernyataan di atas maka dapat disimpulkan bahwa para siswa bersemangat untuk belajar bahasa Inggris dikarenakan ada angan-angan atau cita-cita yang diinginkan. Cita-cita tersebut dijadikan sebagai pegangan untuk terus belajar dan berusaha dalam mencapai tujuan yang diharapkan. Melalui cita-cita dan keinginan para siswa menunjukkan kemampuan terbaiknya untuk dapat meraih tujuannya.

Motivasi merupakan salah satu kunci keberhasilan dan prestasi belajar. Siswa yang memiliki motivasi belajar yang tinggi cenderung akan memiliki nilai yang baik. Kondisi yang terjadi pada siswa beragama Buddha tingkat SMA di Kabupaten Banjarnegara pada dasarnya menunjukkan motivasi yang cukup baik karena terdapat 3 siswa yang masuk dalam kategori motivasi sangat baik dan 6 masuk dalam kategori baik. Namun jika diambil persentase memang tidak dapat dipungkiri bahwa lebih banyak siswa yang masuk dalam kategori motivasi cukup dan bahkan ada yang rendah. Sehingga jika melihat nilai bahasa Inggris siswa yang rendah maka dapat dikatakan bahwa salah satu penyebabnya adalah karena motivasi belajar siswa yang rendah.

Rendahnya motivasi belajar bahasa Inggris siswa lebih banyak disebabkan oleh minimnya kemauan dan dorongan eksternal terutama keluarga untuk senantiasa mengingatkan dan menegur jika terdapat kekeliruan ataupun kekurangan-kekurangan. Peran keluarga masih belum berjalan dengan maksimal dalam upaya memotivasi siswa untuk belajar. Melihat kondisi yang ada hal tersebut 


\section{Jurnal Pendidikan, Sains Sosial dan Agama}

lebih banyak disebabkan oleh latar belakang pendidikan keluarga yang kurang baik serta pekerjaan para anggota keluarga sehingga interaksi yang terjadi antara siswa dan keluarga baik orang tua maupun saudara tidak dapat berjalan dengan baik.

Dalam pembelajaran bahasa Inggris motivasi merupakan salah satu hal yang menjadi faktor penting dalam peningkatan prestasi pembelajaran para pebelajar bahasa kedua. Hal ini sejalan dengan yang disampaikan oleh Shinta (2012: 49) "to learn English, lerarners need motivation since learners need to be driven". Siswa harus memiliki sebuah dorongan tersendiri baik internal maupun eksternal untuk mencapai apa yang diinginkan.

Kemudian jika melihat indikatorindikator yang digunakan untuk mengetahui motivasi belajar diketahui bahwa unsur-unsur dinamis belajar merupakan indikator yang memiliki persentase paling baik dalam memotivasi belajar siswa. Unsur-unsur dinamis belajar memiliki berbagai komponen yang dapat mempengaruhi prestasi belajar siswa. Komponen-komponen tersebut dapat berupa komponen fisik maupun non-fisik. Komponen fisik meliputi berbagai media, bahan, sumber, dan alat pembelajaran sedangkan non fisik dapat berupa faktor internal siswa seperti rasa suka, kedisiplinan, tanggung jawab, dan lainlain.

Unsur-unsur dinamis yang bermacam-macam tersebut memberikan dampak yang besar kepada siswa terkait motivasi belajarnya. Iswahyuni (2017: 38) mengungkapkan bahwa melalui unsur-unsur dinamis belajar siswa akan memanfaatkan berbagai komponen yang berkaitan dengan pembelajaran dimana hal tersebut dapat memotivasi siswa untuk belajar. Unsur-unsur dinamis belajar dapat digunakan sebagai salah satu ukuran untuk meningkatkan motivasi dan prestasi belajar siswa.

Selanjutnya pada faktor demotivasi belajar siswa, bahwa indikator yang memiliki persentase paling tinggi dalam memberikan dampak demotivasi belajar bagi siswa adalah perilaku dan kepribadian guru. Perilaku dan kepribadian guru adalah kunci dari keberhasilan belajar siswa. Guru yang mampu memberikan kenyamanan dalam belajar dan mampu berkomunikasi dengan baik serta memiliki berbagai cara dalam memecahkan solusi pada siswa adalah guru yang disukai oleh banyak siswa.

Dalam kaitannya dengan pembelajaran bahasa Inggris perilaku dan kepribadian guru adalah hal yang sangat penting. Menurut Krashen (dalam Islam, 2015: 10) guru bahasa yang efektif adalah seorang 


\section{Jurnal Pendidikan, Sains Sosial dan Agama}

guru yang mampu memberikan masukan dan menjadikan bahasa lebih mudah dipahami dalam situasi dengan tingkat kecemasan yang rendah. Pembelajaran bahasa Inggris menuntut kemampuan guru dalam memberikan rasa nyaman dan berani selama pembelajaran. Hal ini dikarenakan bahasa Inggris merupakan bahasa asing yang tidak digunakan dalam kehidupan sehari-hari, sehingga siswa perlu didorong untuk berani berbicara bahasa Inggris.

Dalam konteks pengajaran bahasa asing guru yang memiliki kesabaran dan telaten cenderung berhasil dalam meningkatkan kemampuan siswa. Pada umumnya guru-guru bahasa Inggris yang disukai oleh siswa adalah guru-guru yang kreatif dan memiliki kedekatan dengan siswa-siswanya. Hal ini dikarenakan karakteristik bahasa Inggris yang cenderung mengharuskan siswa untuk memiliki kemauan yang tinggi dan keberanian yang baik terutama yang berkaitan dengan kemampuan berbicara bahasa Inggris.

$$
\text { Berdasarkan hasil wawancara, }
$$
observasi, dan dokumentasi diketahui faktorfaktor yang memotivasi siswa dalam pembelajaran bahasa Inggris adalah guru, tantangan, tes, dan cita-cita atau keinginan. Sedangkan faktor-faktor yang menjadi demotivasi siswa pada pembelajaran bahasa Inggris adalah metode pengajaran, kompleksitas materi, kecanduan-e-sports, dan pertemanan di sekolah.

Yang menarik dalam penelitian ini adalah pernyataan sejumlah siswa yang mengungkapkan bahwa dengan adanya tantangan dalam aktivitas pembelajaran maka siswa akan lebih semangat untuk belajar. Menurut Santrock (2007: 358) salah satu cara untuk membuat siswa agar terus berusaha meningkatkan potensi yang dimiliki adalah dengan memberikan hal-hal yang menantang. Pernyataan tersebut mensyaratkan bahwa melalui tantangan siswa akan berusaha untuk meningkatkan berbagai potensi yang dimiliki.

\section{KESIMPULAN}

Motivasi belajar siswa pada pembelajaran bahasa Inggris secara keseluruhan masih kurang baik hal ini dibuktikan dengan persentase siswa yang masuk dalam kategori motivasi cukup dan kurang yang berada di angka di atas 50\%. Faktor-faktor yang menjadi motivasi belajar siswa dalam pembelajaran bahasa Inggris adalah guru, tantangan, tes, dan cita-cita atau aspirasi.

\section{DAFTAR PUSTAKA}

Ahmad, S. (2005). Strtegi Belajar Mengajar. Jakarta: Ciputat Press. 
Arikunto, S. (2013). Prosedur Penelitian:

Suatu Pendekatan Praktik.

Jakarta: RinekaCipta.

Brown, H.D. (2001). Teaching by principles an integrative approach to language pedagogy. New York: Longman.

Gagne, R. M. (1998). The condition of Learning, New York: Holt, Rinehart and Winston.

Hamid, F. A. (1997). Proses Belajar Mengajar Bahasa. Jakarta: Depdikbud Dirjen Pendidikan Tinggi Proyek Mengembangkan LPTK.

Islam, A.M.S. (2015). Faktor Demotivasi dalam Pembelajaran Bahasa Arab di Madrasah. Jakarta: Unpublished Thesis.

Iswahyuni. (2017). Pengaruh Motivasi Belajar terhadap Prestasi Belajar IPS Siswa SMPN 4 Sungguminasa Kabupaten Gowa. Gowa: Unpublished Thesis.

Kholid, I. (2017). Motivasi Dalam Pembelajaran Bahasa Asing.
Jurnal Tadris Bahasa Inggris, Vol 10 (1), 61-71.

Santrock. J.W. (2007). Perkembangan Anak. Jilid 1 Edisi kesebelas. Jakarta: PT. Erlangga.

Shinta, Q. (2012). Peran Motivasi Pada Pembelajaran Bahasa Inggris.Jurnal Teknologi Informasi dan Komunikasi, Vol $3(1), 49-53$.

Uno, H. B. (2016). Teori Motivasi \& Pengukurannya: Analisis di Bidang Pendidikan. Jakarta: Bumi Aksara. 